\title{
Water Quality Index of Kolo Creek, Bayelsa State, Nigeria
}

\author{
${ }^{1}$ EBUETE, AW; ${ }^{2 *}$ BARIWENI, PA \\ Department of Geography and Environmental Management, Niger Delta University, \\ Wilberforce Island, Bayelsa State, Nigeria. \\ *Corresponding Author Email: perekibinabariweni@ndu.edu.ng; +2348035085317; ebuetewilliams@gmail.com; +2348038890102
}

\begin{abstract}
The Kolo Creek was assessed to determine the impact of human activities on the water quality using the Water Quality Index. Water samples were collected from six sample sites (A-F) during the dry and wet seasons and assessed for physicochemical and biological parameters. Results from the study showed a mean e-coli level of $39.83 \pm 2.93$ (Cfu); mean $\mathrm{pH}$ of $7.23 \pm 0.37$ in the dry season and $6.78 \pm 0.18$ for the wet season; and mean DO levels of $7.58 \pm 1.00 \mathrm{mg} / 1 \mathrm{during}$ the dry season and $9.29 \pm 2.67 \mathrm{mg} / \mathrm{l}$ during the wet season indicating that the Kolo Creek was biologically polluted but physicochemical potable for domestic use. However, combined physicochemical and biological classification with the water quality index ranked the creek water as medium (Class III) and not good for consumption. The water quality index was affirmed as a good single measure of water quality.
\end{abstract}

\section{DOI: $\underline{\text { https://dx.doi.org/10.4314/jasem.v23i11.3 }}$}

Copyright: Copyright (C) 2019 Ebuete and Bariweni. This is an open access article distributed under the Creative Commons Attribution License (CCL), which permits unrestricted use, distribution, and reproduction in any medium, provided the original work is properly cited.

Dates: Received: 07 October 2019; Revised: 11 November 2019; 24 November 2019

Keywords: Water Quality, Water Quality Index, Kolo Creek, Niger Delta

Water is a dynamic medium containing living, non living components, organic and inorganic soluble as well as insoluble substances that constitute a support system for living organisms (Al-Mashagbah, 2015). In fact, water stands to be the second most important natural resource for all forms of life after air and is a valuable natural asset which forms the major constituent of the ecosystem (Balan et al., 2012). Despite its abundance, the quality and accessibility of potable water remains a global challenge especially in the rural and semi-rural communities in the developing countries (Ohwo and Abotutu, 2014). Freshwater that is available for drinking, agricultural and domestic purposes is known to be exposed to an array of contamination from uncontrolled human activities (Oribhabor, 2015). The type and severity of water contamination is often directly related to human activity, which can be quantified in terms of the intensity and type of land use in the catchment areas of a water body. With growing human population, increasing urbanisation, industrialisation and environmental degradations, lakes, streams and rivers are increasingly threatened from chemical and biological pollutants. The Kolo Creek is one of the inland water bodies in the Niger Delta receiving organic and chemical wastes arising from anthropogenic activities within the catchment area. Numerous studies have been carried out to assess its water quality (NEDECO, 1961; Inegite et al., 2010; Gobo et al., 2013; Aghoghovulia and Ohimain, 2014; Ogamba et al., 2015; Seiyabor and Ayibaefie, 2017 and Ogamba et al., 2017). None of these studies has generally classified the water quality from the Kolo Creek, because the indices used are either the physico- chemical or biological parameters. This study is aimed at assessing the general water quality of the Kolo Creek using Water Quality Index for missing parameters. Over the last couple of decades, Water Quality Index, which was first developed by Horton in 1965 has been successfully applied in water quality assessment studies in various region of the world under various names such as Weighted Arithmetic Water Quality Index (WAWQI), National Sanitation Foundation Water Quality Index (NSFWQI), Canadian Council of Minister of the Environment Water Quality Index (CCMEWQI), Oregon Water Quality Index (OWQI) etc. (Cude, 2001; Chaturvedi and Bassin, 2010; Sing et al., 2013a; Fadaei and Gafari, 2015). The uniqueness of the use of the water quality index is that it provides the composite influences of individual water quality parameter on the overall quality of water (Sing et al., 2013b). Accordingly, water with a quality index range of $90-$ 100 is classed I and its quality is described as excellent, $70-90$ is classed II and its quality is described as good, $50-70$ is classed III and its quality described as medium, $25-50$ is classed IV and its quality is described as bad and $0-25$ is classed $V$ and its quality described as very bad (Deepika and Sing, 2015). Information on the quality of surface water using water quality index in most streams and rivers in Nigeria is scanty, hence the need for this study.

\section{MATERIAL AND METHODS}

Study Area: Kolo Creek lies within latitude $04^{0} 24^{\prime} 26.893^{\prime \prime}$ and $04^{0} 59^{\prime} 05.094^{\prime \prime}$ North and longitude $06^{0} 14^{\prime} 59.190^{\prime \prime}$ and $06^{0} 20^{\prime} 47.701^{\prime \prime}$ East. The full length of the Kolo Creek is about $85 \mathrm{~km}$, covering a total area

*Corresponding Author Email: perekibinabariweni@ndu.edu.ng; Tel: +2348035085317 
of about 1,625 square kilometers (NEDECO, 1961; Eli, 2012). Kolo Creek is located at the central part of the Niger Delta and transverses about twenty-one (21) communities including Okarki; Otegue II, Ibelebiri, Oruma/Yibama, Otuasega, Imiringi, Emeyal 1 and 2, Kolo 1, 2 and 3, Otuegila, Otakeme, Otuabagi, Ewoma/Otuabi, Otuogidi, Ogbia Town, Otuabo/Abobiri, Ekpenkiri, Akakumama, and Bukiri (Gobo et al., 2013) (Figure 1). The main human activities along the creek include flood plain farming, sand mining, oil palm processing, cassava processing, open defeacation, etc. These activities are known to influence water quality (Izonfuo and Bariweni, 2001; Ayotunde and Bariweni, 2017).

Sampling design and method of data Collection: Water samples were collected from six (6) sampling points labelled A (Okarki); B (Otuasega); C (Imiringi); D (Kolo 2); E (Otuabagi) and F (Ogbia Town) (Figure 1) purposively selected to assess the variation in anthropogenic activities and classify the water quality of the Kolo Creek using Water Quality Index. Samples were collected monthly for a year and analysed by standard methods of APHA (1995) for their physicochemical and biological characteristics. All sampling locations were geo-located using GARMIN 76 hand held GPS equipment. Water Quality Index (WQI) for missing parameter (phosphate) was determined using Equation 1, following the method of Srivastava and Kumar (2013).

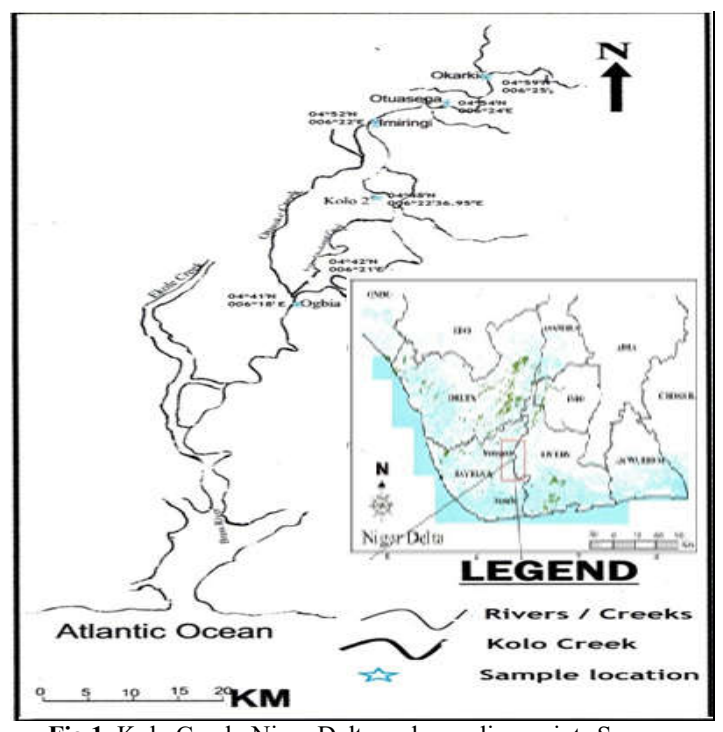

Fig 1. Kolo Creek, Niger Delta and sampling points Source: Adapted from Eli (2012)

$$
\begin{aligned}
\mathrm{WQI}_{\mathrm{MP}} & =\sum \frac{\mathrm{WYQY}}{\mathrm{WY}} \\
\mathrm{WQI}_{\mathrm{MP}}=\Sigma \mathrm{WYQY} / \mathrm{WY} &
\end{aligned}
$$

Where: $\mathrm{WQI}_{\mathrm{MP}}=$ Water Quality Index for Missing parameters, $\Sigma=$ Summation, WY $=$ Weighting Factors of Available Parameters, QY $=$ Q-values of available parameters.
Results obtained from physicochemical and microbiological parameters were transferred to a weighting curve/ chart from which numerical values were obtained. The numerical value or Q-value, which is multiplied by a "weighting factor (Table 1, Equation 1 ), gives an indication of how good or bad the water quality is when summed up; where a value of 100 is Very Good and 1 is Very Bad.

\begin{tabular}{ll} 
Table 1: Weighing Factors of Water Quality Parameters \\
\hline Parameters & Weight Factor \\
\hline Dissolved Oxygen (DO) & 0.17 \\
Total Coliform & 0.16 \\
Potential d'Hydrogene (pH) & 0.11 \\
Biological Oxygen Demand & 0.11 \\
Temperature & 0.11 \\
Nitrates & 0.10 \\
Turbidity & 0.08 \\
Total Dissolved Solute (TDS) & 0.07 \\
\hline \multicolumn{2}{c}{ Source: Srivastava and Kumar, 2013 }
\end{tabular}

\section{RESULTS AND DISCUSSION}

Results of the mean seasonal physicochemical and biological characteristics of the Kolo Creek are presented in Table 2. Results of the individual parameters showed that Dissolved Oxygen (DO) levels were more variable in the wet season than the dry season. The observed seasonal mean levels of $7.58 \pm 1.00 \mathrm{mg} / \mathrm{l}$ during the dry season and $9.29 \pm 2.67 \mathrm{mg} / 1$ during the wet season, which accounted for $10.14 \%$ seasonal difference, were above the recommended permissible limit of $3.0-7.0 \mathrm{mg} / 1$ for drinking water (Nigerian Industrial Standard (NIS), 2007; WHO, 2011). The values obtained agree with the results of Inengite et.al.(2010); Williams and Odokuma (2014); and Daka et al. (2014) for the Kolo Creek. The mean result of the Total-Coliform count for both seasons were above permissible limit of 10 CFU/100ml (NIS, 2007; WHO, 2011). It was observed that the presence of coliforms in the creek decreased downstream $(A>B>C>D>E>F)$. The values obtained from this study compare with the findings of Dami et.al.(2012). Data regarding the mean Hydrogen ions concentration $(\mathrm{pH})$ of the Kolo Creek showed a mean of $7.23 \pm 0.37$ in the dry season and $6.78 \pm 0.18$ for the wet season. The observed seasonal mean $\mathrm{pH}$ levels, which were within the recommended range of 6.5-8.5 for drinking water (NIS, 2007; WHO, 2011) were found to be similar to those of Inengite et. al. (2010); Gobo, et al (2013); and Aghoghovwia and Ohimain (2014). The mean Biochemical Oxygen Demand $\left(\mathrm{BOD}_{5}\right)$ recorded for the dry season was $0.97 \pm 0.20 \mathrm{mg} / 1$ and $0.23 \pm 0.11 \mathrm{mg} / 1$ for the wet season. This accounted for a $61.34 \%$ seasonal difference in the mean $\mathrm{BOD}_{5}$ values. These results were within the permissible limit (NIS, 2007; WHO, 2011) and agrees with those of Ogamba and Ebere (2017) for the Kolo Creek. Results concerning the turbidity levels showed a mean seasonal variation of $0.38 \pm 0.61 \mathrm{NTU}$ for the dry season and $2.68 \pm 0.52 \mathrm{NTU}$ for the wet season. The observed values were below NIS (2007) and WHO (2011) permissible value of 5.00 NTU. The results 
were similar to the report of Seiyaboh et al. (2016) on the Kolo Creek. The mean seasonal Total Dissolved Solids result were within the recommended value of $(500 \mathrm{Mg} / \mathrm{l})$ by the National guideline and standards for water quality in Nigeria (NIS, 2007) and the WHO
(2011) specified limit for drinking water. The results were similar to those of Inengite et al., (2010); Aghoghovwia and Ohimain (2014).

Table 2: Mean seasonal Physicochemical and biological characteristics of the Kolo Creek

\begin{tabular}{llllllllll}
\hline \multirow{2}{*}{ Parameters } & \multicolumn{4}{c}{ Dry Season } & \multicolumn{5}{c}{ Wet Season } \\
\cline { 2 - 9 }$y$ & MIN & MAX & MEAN & STD & MIN & MAX & MEAN & STD \\
\hline DO (mg/l) & 6.00 & 8.80 & 7.58 & 1.00 & 4.00 & 10.81 & 9.29 & 2.67 & $3.0-7.0(\mathrm{WHO}, 2011)$ \\
E-Coli (cfu) & 6.00 & 59.00 & 32.00 & 21.62 & 37.00 & 45.00 & 39.83 & 2.93 & $10(\mathrm{WHO}, 2011)$ \\
PH & 6.80 & 7.70 & 7.23 & 0.37 & 6.50 & 6.90 & 6.78 & 0.18 & $6.5-8.5(\mathrm{WHO}, 2011)$ \\
BOD (mg/l) & 0.68 & 1.20 & 0.97 & 0.20 & 0.08 & 0.40 & 0.23 & 0.11 & $3.0(\mathrm{WHO}, 2011)$ \\
Temperature $\left({ }^{0} \mathrm{C}\right)$ & 31.00 & 32.00 & 31.43 & 0.46 & 28.30 & 28.40 & 28.35 & 0.05 & \\
Nitrates (mg/l) & 96.00 & 100.00 & 98.83 & 1.60 & 86.00 & 92.00 & 87.50 & 2.26 & $9.1(\mathrm{WHO}, 2011)$ \\
Turbidity (NTU) & 0.00 & 1.60 & 0.38 & 0.61 & 2.40 & 3.60 & 2.68 & 0.52 & $5.00(\mathrm{WHO}, 2011)$ \\
TDS (mg/l) & 91.00 & 168.00 & 121.00 & 29.93 & 45.80 & 64.40 & 50.00 & 7.11 & $500(\mathrm{WHO}, 2011)$ \\
\hline Source: Researcher fieldwork
\end{tabular}

Source: Researcher fieldwork, 2017

Table 3: Q-Values of Water Quality Parameters in Sampled Stations

\begin{tabular}{|c|c|c|c|c|c|c|c|c|c|c|c|c|}
\hline \multirow[t]{3}{*}{ Parameters } & \multicolumn{12}{|c|}{ Q- Values For all Stations } \\
\hline & \multicolumn{2}{|c|}{$\mathbf{A}$} & \multicolumn{2}{|c|}{ B } & \multicolumn{2}{|c|}{ C } & \multicolumn{2}{|c|}{ D } & \multicolumn{2}{|c|}{$\mathbf{E}$} & \multicolumn{2}{|l|}{$\mathbf{F}$} \\
\hline & Dry & Wet & Dry & Wet & Dry & Wet & Dry & Wet & Dry & Wet & Dry & Wet \\
\hline DO & 3 & 3 & 3.5 & 4 & 4 & 6 & 4.5 & 8 & 4.5 & 8 & 4.7 & 9 \\
\hline E-Coli & 52 & 35 & 53 & 56 & 55 & 54 & 53 & 52 & 65 & 56 & 64 & 52 \\
\hline $\mathrm{PH}$ & 90 & 75 & 92 & 75 & 94 & 75 & 92 & 75 & 89 & 70 & 88 & 68 \\
\hline BOD & 97 & 95 & 100 & 96 & 97 & 96 & 100 & 97 & 99 & 97 & 100 & 99 \\
\hline Temperature & 1.9 & 39 & 2.7 & 39 & 2.7 & 39 & 1.9 & 39 & 1.9 & 39 & 1.9 & 39 \\
\hline Nitrates & 96 & 86 & 98 & 86 & 99 & 87 & 100 & 87 & 100 & 87 & 100 & 92 \\
\hline Turbidity & 98 & 88 & 98 & 88 & 99 & 78 & 98 & 79 & 99 & 78 & 99 & 70 \\
\hline TDS & 74 & 85 & 77 & 84 & 81 & 84 & 83 & 84 & 85 & 86 & 87 & 83 \\
\hline
\end{tabular}

Table 4: Summary of Computed WQI across Stations for two seasons

\begin{tabular}{|c|c|c|c|c|c|c|c|c|c|c|c|c|}
\hline \multirow[t]{3}{*}{ WQI } & \multicolumn{12}{|c|}{ Station } \\
\hline & \multicolumn{2}{|c|}{$\mathbf{A}$} & \multicolumn{2}{|c|}{ B } & \multicolumn{2}{|c|}{$\mathrm{C}$} & \multicolumn{2}{|c|}{ D } & \multicolumn{2}{|c|}{$\mathbf{E}$} & \multicolumn{2}{|c|}{$\mathbf{F}$} \\
\hline & Dry & Wet & Dry & Wet & Dry & Wet & Dry & Wet & Dry & Wet & Dry & Wet \\
\hline$\overline{\Sigma Q_{Y}}$ & 55.9 & 53.9 & 57.2 & 54.3 & 57.9 & 53.6 & 57.9 & 53.8 & 59.6 & 53.9 & 59.6 & 53.12 \\
\hline$\Sigma \mathrm{W}_{\mathrm{Y}}$ & 0.91 & & 0.91 & & 0.91 & & 0.91 & & 0.91 & & 0.91 & \\
\hline$\Sigma$ WQI & 61.4 & 59.2 & 62.8 & 59.7 & 63.7 & 58.9 & 63.6 & 59.1 & 65.5 & 59.3 & 65.5 & 58.22 \\
\hline$\overline{\mathrm{x}}$ & $\overline{\mathrm{x}} \Sigma \mathrm{D}$ & $=63.7$ & and $\bar{x}$ & $\mathrm{VQI}_{\mathrm{mp}}$ & $8.22 ; \overline{\mathrm{x}}$ & $\mathrm{DQI}_{\mathrm{m}}$ & $\overline{\mathrm{x}} \Sigma \mathrm{DQ}$ & $+\overline{\mathrm{X}} \Sigma \mathrm{V}$ & {$[\mathrm{mp} / 2)$} & 0.97 & & \\
\hline
\end{tabular}

Sources: Fieldwork, 2017

Where: $x \sum D Q I=$ Sum of water quality index during the dry season, $x \sum W Q I=$ Sum of water quality index during the wet season, $x \sum W D Q I=$ Sum of water quality index during the dry and wet season

Results of all the individual parameters as observed in the study appear to indicate that the kolo creek water quality were within acceptable limits except for those of total coliforms and the DO levels. The water quality may therefore be classified as polluted on the basis of an individual water quality characteristics. As stated earlier, the WQI classifies water quality according to the degree of purity by incorporating multiple water quality parameters into mathematical equation that rates the health status of water with a single number (Ayobahan et al., 2014). Result obtained from conversion of raw data to Q-values is presented in Table 3 and the summary of the WQI is presented in Table 4. Results from the summary classified water quality of the Kolo creek as Class III, which is scientifically described as "Medium". The water quality status from the computed water quality index also revealed slight quality differences from source to mouth in an order of $\mathrm{F}>\mathrm{E}>\mathrm{C}>\mathrm{D}>\mathrm{B}>\mathrm{A}$ during the dry season and $\mathrm{B}>\mathrm{E}>\mathrm{A}>\mathrm{D}>\mathrm{C}>\mathrm{F}$ during the wet season (Table 4). Obviously, water quality of the Kolo Creek was practically determined by the types of anthropogenic activities operating within its catchment indicating the variation in impact of human activities on water quality with the seasons. The percentage differences between the dry season and the wet season samples accounted for $4.52 \%$ which was very minute compared to the differences in anthropogenic activities. Mustapha and Aris (2011); Eli (2012); RimRukeh and Agbozu (2013); Etim et al. (2013); Olowe et al. (2016); Seiyaboh and Izah (2017); had linked types and severity of water contamination to the human activities, which can be quantified in terms of the intensity and types of land use of the area.

Conclusion: The results from this study has demonstrated the usefulness of the water quality index in providing the composite impact of individual water quality parameter on the overall quality of water. Therefore, instead of using just the physicochemical or biological parameters in assessing water quality, a combination of these is recommended using the water quality index. 


\section{REFERNCES}

Aghoghovwia, OA; Ohimain, EI. (2014): Physicochemical characteristics of Lower Kolo Creek, Otuogidi, Bayelsa State. Nig. J. Agric. Food. Environ. 10(1):23-26.

Al-Mashagba, A. (2015): Assessmant of Surface Water Quality of King Abdullah Canal Using Physicochemical Characteristics and Water Quality Index, Jordan. J. Water Res. Protect.7:339-352,

American Public Health Association (APHA) (1995): Standard methods for the examination of water and waste water. American public health association inc. New York 619Pp.

Ayobahan, SU; Ezenwa, IM; Orogun, EE; Uriri, JE; Wemimo, IJ (2014): Assessment of Anthropogenic Activities on Water Quality of Benin River. J. Appl. Sci. Environ. Manage. 18 (4) $629-636$

Ayotunde, O; Bariweni, PA (2018): Impact of urban runoff on the concentration of heavy metals in the Epie Creek, Niger Delta, Nigeria. WJS S, 3, 1, 1219

Balan, IN; Shivakumar, M Kumar, PDM (2012): An assessment of ground water quality using water quality index in Chennai, Tamil Nadu, India. Chronicles Young Scientists, 3(2):146-150.

Chaturvedi MK; Bassin JK (2010): Assessing the water quality index of water treatment plant and bore wells, in Delhi, India. Environ. Monit. Assess. 163:449-453.

Cude, C. (2001). Oregon Water Quality Index: A tool for evaluating water quality management effectiveness. J. Amer. Water Res. Ass, 37:125137.

Daka, ER; Amakiri-Whyte; Inyang, IR (2014): Surface and Groundwater Quality in Some Oil Field Communities in the Niger Delta: Implications for Domestic Use and Building Construction, Res. J. Environ. Earth Sci. 6(2): 7884

Deepika, R; Singh, SK (2015): Water quality index assessment of Bhalswa Lake, New Delhi. Int. J. Adv. Res. 3(5):1052-1059.

Dami, A; Ayuba, HK; Amukali, O (2012): Physicochemical and Bacterialogical Analysis of the Surface Water Used for Domestic Purposes in Okpai and Beneku, Delta State, Nigeria. Global J. Human Soc. Sci. 12 (13):30-37
Eli, HD (2012): Analysis of flooding on farmlands along the Kolo Creek of Bayelsa State, Nigeria. Unpublished Ph.D. Thesis, University of Calabar, Nigeria

Etim, E, Odoh, R, Itodo, AU; Umoh, SD; Lawal, U. (2013): Water Quality Index for the Assessment of Water Quality from Different Sources in the Niger Delta Region of Nigeria. Frontiers in Science. 3(3):89-95

Fadaei, A; Gafari, M. (2015): Physico-chemical assessment of the Zayandeh-Rud River, Iran, using water quality index. J. Applied Sci. in Environ. Sanitation; 9(3):199-204.

Gobo, AE; Amangabara, GT; Etiga, GE (2013): Estimating Macrophyte Load for Water Hyacinth in the Kolo Creek, Niger Delta. International Journal of Ecosystem, 3(1):7-11

Inengite, AK; Oforka, NC; Osuji, LC (2010): Survey of Heavy Metals in Sediments of Kolo Creek in the Niger Delta, Nigeria. African Journal of Environmental Science and Technology. 4(9):558-566.

Izonfuo, LW-A; Bariweni, AP (2001): The Effect of Urban Runoff Water and Human Activities on Some Physico-Chemical Parameters of the Epie Creek in the Niger Delta. J Appl. Sci. Environ. Mgt., 5: 47-55.

Mustapha, A; Aris, AZ (2011): Application of Water Quality Index method in Water quality assessment, Intl. J. Water Resources, 34(7):192198.

Netherlands Engineering Consultants (NEDECO) (1961): The Waters of the Niger Delta. The Hague, the Netherland.

Nigerian Industrial Standard (2007): Nigerian Standard for Drinking Water Quality (NIS 554:2007), Standard Organization of Nigeria $(S O N)$. Price group D.

Ogamba, EN; Ebere, N; Izah, SC (2017): Heavy metal Concentration in water, sediment and Tissues of Eichhornia Crassipes from Kolo Creek, Niger Delta, Greener J. Environ. Manage. Public Safety, 6(1):1-5.

Ogamba, EN; Seiyaboh. EI; Izah, SC; Ogbugo. I; Demedonha, FA (2015): Water Quality Phytochemistry and Proximate Constituents of Eichhonia Crassipes from Kolo Creek, Niger Delta, Nigeria. Int. J. Appl. Res. Technol. 4 (9):7784. 
Ogamba, EN; Ebere, N. (2017): Assessment of physiochemical Quality of Sediment from Kolo Creek, Niger Delta, Greener J. Biol. Sci. 7(2):2024.

Ohwo, O; Abotutu, A. (2014): Access to Potable Water supply in Nigerian Cities. Evidence from Yenagoa Metropolis. American Journal of Water Resources, 2(2). Available on www.scipub.com/journal/AJWR.

Olowe, BM; Oluyege, JO; Famurewa, O. (2016): An Assessment of Drinking Water Quality Using Water Quality Index in Ado-Ekiti and Environs, Nigeria, Am. Chem. Sci. J., 12(2):1-7

Oribhabor, BJ (2015): Impact of human activities on biodiversity in the Nigerian aquatic ecosystems, Sci. Intern, 4: 12-20.

Rim-Rukeh, A; Agbozu, LE (2013): Impact of Partially treated sewage effluents on the water quality of recipient Epie Creek, Niger Delta, Nigeria using Malaysian Water Quality Index 24.

(WQI). J .Appl .Sci. Env. Manage. 7(2):20-

Seiyaboh, EI; Ayibaefie, YW (2017): Assessment of Hydrocarbon Level in Surface Water Aligning of Imiringi Oil field Facilities in the Niger Delta. Intern. J. Innov. Biosci. Res, 5(3) 1-9.

Seiyaboh, EI; Izah, SC. (2017): Review of Impact of Anthropogenic Activities in surface water resources in the Niger Delta Region of Nigeria: A case of Bayelsa State, Int. J. Ecotoxicology and Ecobiology, 2(2):61-73.
Seiyaboh, EI; Alagha, WE; Gijo, AH (2016): Spartial and Seasonal Variation in Physicochemical Quality of Ekoli Creek, Niger Delta, Nigeria, Greener J. Environ. Manage Public Safety, 5(5): 104-109.

Sing, PK. Tiwari, AK and Mahato, MK (2013a): Quality Assessment of surface water of west Bokaro Coalfield, Jharkhand by using Water Quality Index Method. Inter. J. Chem. Tech Res. 5(5): 123-130.

Sing, PK; Tiwari, AK; Panigarhy, BP;.Mahato, MK. (2013b): Water Quality Indices used for water resources vulnerability assessment using GIS Techniques. A review, Inter. J. Earth Sci. Engineer. 6 (6-1): 1594-1600

Srivastava, G; Kumar, P. (2013): Water Quality Index with Missing Parameters. Inter. J. Res. Engineer. Technol. 2(4), 609-614

Williams, JO; Odokuma, LO (2014): Modeling of Physiochemical Fate of a Simulated Oil Spill in Brackish Surface Water of Niger Delta, Nigeria. Inter. J. Current Res. Academic Rev. 2(9):141152

World Health Organization (2011): Guideline for Drinking Water Quality, (4th Ed.). [Online] Available:http://www.who.int/water_sanitation_ health/publications/2011/dwq_chapters/en. 